\title{
Brand Attitude of Smartphone User: The Role of Brand Knowledge and Self-Congruence
}

\author{
Ali Mohamad Rezza \\ Sekolah Pasca Sarjana \\ Universitas Pendidikan Indonesia \\ Bandung, Indonesia \\ alimohamad.rezza@student.upi.edu
}

\begin{abstract}
- this study examines the brand attitudes of smartphone user. In particular, it examines how users brand knowledge and their self-image congruence can affect their brand attitudes towards smartphone products. Previous research indicates that brand knowledge and self-congruence can facilitate positive behavior and attitude towards products. This research used cross-sectional survey explanatory method and structural equation modelling approach to test the hypothesis. A questionnaire was sent to 200 smartphone users in Bandung. Results indicate that self-congruence was a good predictor of user's brand attitude and brand knowledge did not affect user's brand attitude towards smartphone product.
\end{abstract}

Keywords - brand attitude;brand knowledge; self-image congruence; smartphone

\section{INTRODUCTION}

The number of Internet users in Indonesia is approximately 88.1 million and as much as $85 \%$ of the users, frequently access the Internet using mobile phones [1]. This fact has led also to the increasing trend in the use of smartphones in Indonesia, because internet access becomes easier when using smartphone. With many Internet users and the unique behavior in making internet access make smartphone market in Indonesia is very potential according to smartphone manufacturers.

TABLE I. PREDICTION OF SMARTPHONE GROWTH IN The Asia PASIFIC

\begin{tabular}{|c|c|c|c|c|c|}
\hline \multirow{2}{*}{ Country } & \multicolumn{5}{|c|}{$\begin{array}{c}\text { Number of Smartphone User } \\
\text { (In Millions) }\end{array}$} \\
\cline { 2 - 6 } & $\mathbf{2 0 1 5}$ & $\mathbf{2 0 1 6}$ & $\mathbf{2 0 1 7}$ & $\mathbf{2 0 1 8}$ & $\mathbf{2 0 1 9}$ \\
\hline China & 525.8 & 563.3 & 599.3 & 640.5 & 687.7 \\
\hline India & 167.9 & 204.1 & 243.8 & 279.2 & 317.1 \\
\hline Indonesia & 55.4 & 65.2 & 74.9 & 83.5 & 92.0 \\
\hline Japan & 51.8 & 55.8 & 58.9 & 60.9 & 62.6 \\
\hline South Korea & 33.6 & 34.6 & 35.6 & 36.5 & 37.0 \\
\hline Philippines & 26.2 & 29.9 & 33.3 & 36.5 & 39.2 \\
\hline Vietnam & 20.7 & 24.6 & 28.6 & 32.0 & 35.2 \\
\hline
\end{tabular}

Many emerging new brands in the smartphone marke Indonesia, whether local and global brands caused fierce competition in Indonesian market. Every manufacturer offers a large selection of smartphones to consumers, ranging from series, features, service and of course price. In order to face tight competition, it requires constant innovation in order to provide more value for consumers and eventually be able to give the company a competitive advantage compared to its competitors.

TABLE II. TOP FIVE SMARTPHONE VENDORS AND MARKET SHARE 2015 IN INDONESIA

\begin{tabular}{|c|c|c|c|c|c|}
\hline Vendor & $\begin{array}{c}2015 \\
\text { shipment } \\
\text { volume } \\
\text { (millions) }\end{array}$ & $\begin{array}{c}2015 \\
\text { Market } \\
\text { share } \\
(\%)\end{array}$ & $\begin{array}{c}2014 \\
\text { shipment } \\
\text { volume } \\
\text { (millions) }\end{array}$ & $\begin{array}{c}2014 \\
\text { Market } \\
\text { share } \\
(\%)\end{array}$ & $\begin{array}{c}\text { Year- } \\
\text { over } \\
\text { year } \\
\text { Growth } \\
(\%)\end{array}$ \\
\hline Samsung & 7.3 & 24.8 & 6.8 & 27.0 & 7.5 \\
\hline Asus & 4.7 & 15.9 & 1.4 & 5.6 & 231.4 \\
\hline Smartfren & 3.2 & 10.8 & 2.6 & 10.2 & 23.7 \\
\hline Advan & 2.8 & 9.6 & 2.3 & 9.2 & 21.5 \\
\hline Lenovo & 1.9 & 6.5 & 1.4 & 5.8 & 31.3 \\
\hline Others & 9.5 & 32.5 & 10.6 & 42.2 & -9.8 \\
\hline Total & 29.3 & 100 & 25.0 & 100 & 17.1 \\
\hline
\end{tabular}

For consumers, the emergence of many smartphone's brand that offer a lot of things like that, can only bring confusion when selecting a product or brand and consumer is also faced with many stimuli of marketing that will actually make consumers become bored and will negatively affect their behavior towards the brand [4]. In Indonesian market, there are around 30-40 smartphone brands from global and local brand, and they actively give a lot of marketing programs to the consumer like sales promotion and advertising, events and experience, mobile marketing, etc. that made consumer is over exposed to marketing activity.

These conditions make harder for consumer to choose a brand/product and also affected the attitude of consumer towards smartphone brand/products. Selection to a brand can be based on the behavior of consumers towards the brand [5]; therefore, the formation of positive attitudes toward the brand becomes very important. This study focused on how the formation of attitudes towards brands when associated it with self-concept and brand knowledge.

The literature on consumer behavior has long supported the proposition that the purchasing behavior can be influenced by an individual's self-concept [6]-[9]. The motivation to be able to express yourself can be a force for buying goods or using services [8]. In an environment of intense competition, the selection of a brand can be also influenced by the suitability / appropriateness of consumer's self-perceptions with the brand personality contained in the product; therefore, it is very 
important as to how to create a brand personality that matches the self-concept of target consumers so that they can shape behavior positively to the brand. B attitude is influenced by consumer knowledge and beliefs about the brand. The more positive they are, the easier it is for consumer to retrieve or recall the brand [10] and also it can influence the attitude formation towards the brand.

Previous studies had a lot of explaining that the individual self-concept and brand knowledge can be associated with product and brand preferences, product and brand selection, customer satisfaction and store loyalty [8], [10]-[13], but in the context of the smartphone market in Indonesia is still not a lot of studies that examined the association of self-congruity and brand knowledge to the formation of brand attitude.

The aim of this study is to investigate the description of self-congruity, brand knowledge, brand attitude by smartphone users in Indonesia and find out the influence of self-congruity and brand knowledge on brand attitude.

\section{THEORETICAL REVIEW}

\section{A. Brand Attitude}

Brand attitude is one of the key elements on achieving brand equity. Marketers have long invoked the construct of brand attitude as key antecedents to consumer behavior [14]. The definition of brand attitude is the overall evaluation of individual toward a brand, usually the basis of brand choice and also an evaluation of expected capacity to deliver a currently relevant buying motive [5], [15], [16]. In the evaluation process, consumers consider many things and one of them is the self-concept congruity with the brand. This means the emergence of attitude toward a brand from the consumer perspective is the result of perceptions of themselves regarding a brand, and it can be a predictor of consumer's behavior towards the brand [17].

\section{B. Brand Knowledge}

Brand knowledge is defining as a network of nodes and links wherein the brand node in memory has a variety of associations linked to it [5]. Brand knowledge has two components: brand awareness and brand image. Brand awareness is the ability of consumers to recall or recognize the brand under different conditions, and brand image is consumer perceptions of brands as reflected by the associations held in the consumer's memory [5]. In other words, it can be said that perception is created from consumer's knowledge about the brands. Through exposure to a brand, consumers build brand knowledge that consisting of a set of associations regarding the brand [18]. These associations can be an indicator of brand strength and also favorability [18], [19]. Brand knowledge can be created by consumer and marketers alike, with powerful brand knowledge can generate trust and experience for consumer. Creation of brand knowledge is actually a process of converting the trust into the experience and vice versa. Positive experience and high trust to a brand will bring positive attitude towards the brand [20].

$\mathrm{H} 1$ = Brand knowledge has a significant and positive effect on brand attitude.

\section{Self-congruity}

The term self-congruity was starting to emerge when Rosenberg introduced a theory of self-concept in 1979. The definition of self-concept is the totality of the individual's thoughts and feelings having reference to him as an object [8]. Self-concept is construed into two perspectives: the actual self and the ideal self. Both dimensions can affect consumers when evaluating brands. Consumer efforts to match himself with a brand that is known as self-congruity. Self-congruity theory states that consumers prefer a brand that in line with their selfimage. Past research [9], [21] has suggested that consumer will choose or have positive attitude towards the brands that are perceived to have strong favorable human characteristics that are congruent with his or her self-concept. Self-congruence proved to have important roles in consumer decision-making and motivation [11] and it also very persuasive as it often motivates consumer irrationally through their emotion [22]. Past researches showed that self-congruence can be a basis for consumer to give an evaluation of the brand through the congruity of consumer's self-concept with the brand. Self congruity can increase positive behaviors of consumers towards the brand [17].

H2: Self-congruity has a significant and positive effect on brand attitude.

\section{RESEARCH METHODOLOGY}

This study included students at two private universities in Bandung. Students serve as respondents because they are very familiar with smartphone products and its brands. The type of research is descriptive verification using cross-sectional survey explanatory. The sampling technique using simple random sampling and Structural Equation Modelling using software from SPSS Amos 20 was used to test the hypothesis.

\section{A. Measurement Scale Development}

This study uses measurement scale that has been widely used in previous studies on self-congruence and brand attitude. All the question in the questionnaire has been translated into Indonesian in order to ease the respondents when answering the questionnaire. Self-congruity measurement scale using the scale used by Sirgy et al, which consists of two statements that examined the actual and ideal self-congruity, each statement was assessed using a five-point Likert scale [7], [9]. Brand knowledge is measured using a five-point Likert scale by using three statements that measure the level of their knowledge of the brand [20]. Brand attitude using a scale from previous studies in which respondents were asked to answer six questions with a five-point Likert scale [23]. 
TABLE III. MEASUREMENT SCALE

\begin{tabular}{|l|l|}
\hline \multicolumn{2}{|c|}{$\begin{array}{c}\text { Brand Knowledge } \\
\text { [20] 5-point scale }\end{array}$} \\
\hline x3 & $\begin{array}{l}\text { When compared to other people, I know a lot about this } \\
\text { brand. }\end{array}$ \\
\hline x4 & My friends considered me as an expert regarding this brand \\
\hline x5 & I considered myself very experienced with this brand \\
\hline \multicolumn{2}{|c|}{$\begin{array}{l}\text { Self-congruence } \\
\text { [9] 5 point scale }\end{array}$} \\
\hline x1 & $\begin{array}{l}\text { The typical user of this brand is consistent with how I see } \\
\text { myself }\end{array}$ \\
\hline x2 & $\begin{array}{l}\text { The typical user of this brand is consistent with how I like to } \\
\text { see myself }\end{array}$ \\
\hline & \multicolumn{1}{c|}{ Brand attitude } \\
& [23] 5 point scale \\
\hline y1 & This brand is good \\
\hline y2 & This brand is attractive \\
\hline y3 & This brand is interesting \\
\hline y4 & This brand is appealing \\
\hline y5 & This brand is like \\
\hline y6 & This brand is pleasent \\
\hline
\end{tabular}

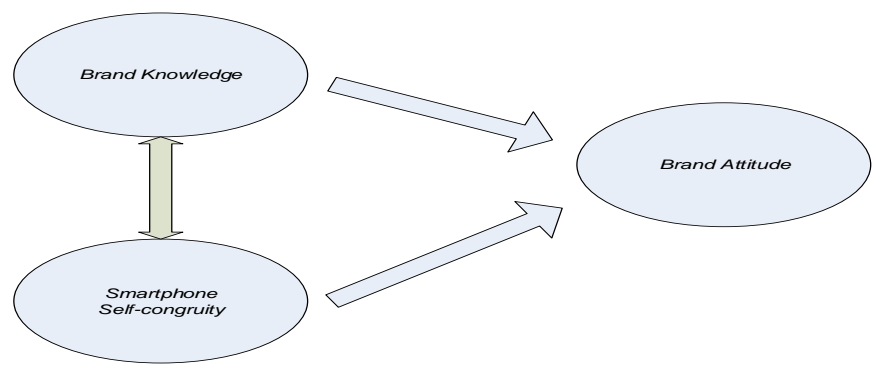

Fig. 1. Research Model

\section{RESULT AND DISCUSSION}

\section{A. Characteristics of Sample}

This study used a questionnaire with a sample size of 200 , but the questionnaire that meets the requirements to be used in this study was 116 . As many as $51.4 \%$ of respondents were male, and the remaining $48.6 \%$ were women. Last education level of the respondents is high school (100\%) because they all are college students. As many as $50 \%$ of respondents own an iPhone; 35\% had a Samsung, and the rest have a smartphone with a variety of brands such as Oppo, MI, LG, and Sony. Most familiar brand of smartphone is iPhone (44.83\%), Samsung (29.31\%), Sony (8.62\%) and the rest (17.24\%) is a combination of various brands such as Nokia, Lenovo, MI, Oppo and others.

\section{B. Confirmatory Factor Analysis}

To evaluate the goodness of fit (GOF) between the data and the model, assessment was done based on the absolute and incremental GOF value. The results can be concluded that the measurement model fits quite well with the data $(\mathrm{GFI}=0.9$; $\mathrm{RMR}=0.05 ; \mathrm{RMSEA}=0.077 ; \mathrm{AGFI}=0.85 ; \mathrm{CFI}=0.93)$.

\section{Hypotheses Testing}

SEM was run to investigate the causal relationships of the constructs proposed in the theoretical framework. One hypothesis was supported out of two proposed hypotheses. Hypotheses 1 investigated effect of brand knowledge on brand attitude. Path coefficient between brand knowledge to brand attitude has negative value therefore it is not supporting the relationship between brand knowledge and brand attitude. Selfcongruence influenced brand attitude $(\beta=0.61)$, therefore supporting $\mathrm{H} 2$.

TABLE IV. PATH ANALYSIS TEST OF HYPOTHESIS

\begin{tabular}{|l|l|c|c|l|l|}
\hline Hypothesis & \multicolumn{1}{|c|}{ Path } & Est & C.R & Signifikansi & Conclusion \\
\hline H2 & $\begin{array}{l}\text { Self } \\
\text { congruity } \\
\rightarrow \text { brand } \\
\text { attitude }\end{array}$ & 0,61 & 3,429 & Significant & $\begin{array}{l}\text { H2 } \\
\text { Supported }\end{array}$ \\
\hline H1 & $\begin{array}{l}\text { Brand } \\
\text { knowledge } \\
\rightarrow \text { brand } \\
\text { attitude }\end{array}$ & $-0,50$ & 0,433 & $\begin{array}{l}\text { Not } \\
\text { Significant }\end{array}$ & $\begin{array}{l}\text { H1 } \\
\text { not } \\
\text { supported }\end{array}$ \\
\hline
\end{tabular}

Source: Processed Data

\section{Discussion}

The results of this study show that the self-congruity effect on brand attitude and brand knowledge has no effect on brand attitude.

The development of marketing strategy is directed at efforts to build clear brand personality and in accordance with the intended target market. Brand personality has to be adjusted with the self-concept of consumer target markets therefore marketers should identify very clearly the self-concept of consumers to match the brand personality of the product. If it matches the behavior of consumers towards the brand will become more positive. The similarity between the self-image of consumers with brand personality provides a positive role towards the establishment of consumer behavior [11], [21], [24]. Self-congruity model have a hypothesis that the desired brand attitude will happen when there is a match between the consumer's self-image with the image of the brand [25].

The results of this study indicate that brand knowledge does not significantly affect the brand attitude, this result is not consistent with other studies that indicate that brand knowledge is a strong determinant of the behavior of consumers [26], [27]. This indicates that high brand knowledge does not necessarily make more positive attitude toward the brand. There is a possibility in this study, the attitude of respondents to the brand is influenced by other factors such as social factors or groups that made the lack of involvement when choosing a product. Abundant information about a brand this day makes easier for consumer to evaluate the brand i.e. when consumer wants to buy products they just access review site and read numerous review about the brand from other consumer that had used the product or brand. This kind of behavior makes lack of involvement when choosing the brand, they make the decision based on the opinions of other. Brand knowledge has two dimensions: brand awareness and brand image where there are trusts in the brand. Creation of brand knowledge is a process of 
converting the trust into the experience and vice versa, therefore in its creation required the exchange of information between marketers and consumers. Brand knowledge is related with certain quality associations the consumer links to the brand and it can work both directions, in the perspective of brand and also from consumer mind. So in many ways there are relationships of brand knowledge to the response of consumer.

\section{E. Conclusions}

This study provides further additional knowledge about the influence of self-congruity and brand knowledge on brand attitude, especially in the smartphone market. Self-congruity may significantly affect brand attitude, which is in line with previous studies, and strengthens the theory about this subject. The results of this study on brand knowledge, is not in line with previous studies. Brand knowledge does not affect brand attitude.

\section{F. Limitations and Future Research}

Limitations of this study are not maximal respondents in answering a questionnaire. This may be due to the lack of clarity of the questions in the questionnaire, the lack of explanation of the items and the use of biased phrase in the question.

For further research that can be done is strengthening the measurement scales of self-congruity, gives the relationship between brand knowledge with self-congruity because it is likely a reflection of themselves be influenced by the knowledge-both from experience and trust - generated during contact with the brand.

\section{REFERENCES}

[1] A. P. J. I. I. APJII, “Pengguna Internet Indonesia Tahun 2014,” 2015.

[2] emarketer.com, "Asia-Pacific Boasts More Than 1 Billion Smartphone Users -," $2015 . \quad$ [Online]. Available: http://www.emarketer.com/Article/Asia-Pacific-Boasts-More-Than-1Billion-Smartphone-Users/1012984. [Accessed: 16-Jul-2016].

[3] M. W. Hidayat, "IDC Rilis Data Pasar Smartphone Indonesia pada 2015, Siapa Juara?," Liputan 6.com, 2016. [Online]. Available: http://tekno.liputan6.com/read/2441541/idc-rilis-data-pasar-smartphoneindonesia-pada-2015-siapa-juara. [Accessed: 15-Jul-2016].

[4] W. D. Hoyer, D. J. Macinnis, and R. Pieters, Consumer Behavior, 6th ed. South-Western Cengage Learning, 2013.

[5] K. L. Keller, Strategic Brand Management -Building, Measuring and Managin Brand Equity-, 4e ed. Pearson Education, 2013.

[6] S. Hosany and D. Martin, "Self-image congruence in consumer behavior," J. Bus. Res., vol. 65, pp. 685-691, 2012.

[7] F. Kressmann, M. J. Sirgy, A. Herrmann, F. Huber, S. Huber, and D. Lee, "Direct and indirect effects of self-image congruence on brand loyalty," J. Bus. Res., vol. 59, pp. 955-964, 2006.

[8] M. J. Sirgy, "Self-concept in critical Review Consumer Behavior," $J$. Consum. Res., vol. 9, no. 3, pp. 287-300, 1982.
[9] M. J. Sirgy, D. Grewal, T. F. Mangleburg, J.-O. Park, K.-S. Chon, C. B. Claiborne, J. S. Johar, and H. Berkman, "Assessing the Predictive Validity of Two Methods of Measuring Self-Image Congruence," $J$. Acad. Mark. Sci., vol. 25, no. 3, pp. 229-241, 1997.

[10] Y. D. D. M. Yalcin, D. R. Eren-Erdogmus, and S. Dem, "Using Associations To Create Positive Brand Attitude for Generation Y Consumers: Application in Fashion Retailing," J. Fac. Econ. Adm. Sci., vol. 14, no. 2, pp. 261-276, 2009.

[11] A. Aguirre-rodriguez, M. Bosnjak, and M. J. Sirgy, "Moderators of the self-congruity effect on consumer decision-making: A meta-analysis," J. Bus. Res., vol. 65, pp. 1179-1188, 2012.

[12] A. Beerli, G. D. Meneses, and S. M. Gil, "Self-congruity and destination choice," Ann. Tour. Res., vol. 34, no. 3, pp. 571-587, 2007.

[13] G. Das, "Impacts of retail brand personality and self-congruity on store loyalty:IrThe moderating role of gender," J. Retail. Consum. Serv., 2013.

[14] C. Whan Park, D. J. MacInnis, J. Priester, A. B. Eisingerich, and D. Iacobucci, "Brand Attachment and Brand Attitude Strength: Conceptual and Empirical Differentiation of Two Critical Brand Equity Drivers," $J$. Mark., vol. 74, no. 6, pp. 1-17, 2010.

[15] J. C. Olson and A. A. Mitchell, "Are Product Attribute Beliefs the Only Mediator of Advertising Effects on Brand Attitude?," J. Mark. Res., vol. 18, no. 1, pp. 318-332, 1981.

[16] J. R. Rossiter, “'Branding' explained: Defining and measuring brand awareness and brand attitude," J. Brand Manag., vol. 21, no. November, pp. 533-540, 2014.

[17] F. Liu, J. Li, D. Mizerski, and H. Soh, "Self-congruity, brand attitude, and brand loyalty: A study on luxury brands," Eur. J. Mark., vol. 46, no. 7/8, pp. 922-937, 2012.

[18] H. Mühlbacher, K. Raies, R. Grohs, and O. Koll, "Drivers of brand strength: Configural paths to strong cognitive brand equity," J. Bus. Res., 2015.

[19] H. S. Krishnan, "Characteristics of memory associations: A consumerbased brand equity perspective," Int. J. Res. Mark., vol. 13, no. 4, pp. 389-405, 1996.

[20] R. Algesheimer, U. M. Dholakia, and A. Herrmann, "The Social Influence of Brand Community: Evidence from European Car Clubs," $J$. Mark., vol. 69, no. 3, pp. 19-34, 2005.

[21] M. J. Sirgy, "Self-Congruity Versus Functional Congruity: Predictors of Consumer Behavior," J. Acad. Mark. Sci., vol. 19, no. 4, pp. 363-375, 1991.

[22] Y. Jie, T. Chou, and N. Chou, "Assessing the fi t of two brand personality scales in a Chinese context and revisiting the predictive selfcongruity," J. Brand Manag., vol. 19, no. 6, pp. 525-540, 2011.

[23] H. Li, T. Daugherty, and F. Biocca, "Impact of 3-D advertising on product knowledge, brand attitude, and purchase intention: The mediating role of presence," J. Advert., vol. 31, no. 3, pp. 43-57, 2002.

[24] M. J. Sirgy and C. Su, "Destination Image, Self-Congruity, and Travel Behavior: Toward an Integrative Model," J. Travel Res., vol. 38, no. 4, pp. 340-352, 2000.

[25] B. T. Parker, "A comparison of brand personality and brand user-imagery congruence," J. Consum. Mark., vol. 26, no. 3, pp. 175184, 2009.

[26] F.-R. Esch, T. Langner, B. H. Schmitt, and P. Geus, "Are brands forever? How brand knowledge and relationships affect current and future purchases," J. Prod. Brand Manag., vol. 15, no. 2, pp. 98-105, 2006.

[27] O. Koll and S. Von Wallpach, "One brand perception? Or many? The heterogeneity of intra-brand knowledge," J. Prod. Brand Manag., vol. 18 , no. 5, pp. 338-345, 2009. 